\title{
Global Imbalances and East Asian Currencies ${ }^{\dagger}$
}

\author{
Eiji Ogawa* \\ Hitotsubashi University
}

\begin{abstract}
This paper considers a causality relationship from the global imbalances to the global financial crisis and asymmetric reactions of East Asian currencies to the global financial crisis. In addition, it is pointed out that regional monetary coordination is necessary for stability of intra-regional exchange rates among East Asian currencies. It considers what we should do for the regional monetary coordination in East Asia.
\end{abstract}

\section{JEL Classification: F31, F32, F33}

Keywords: Global imbalances, global financial crisis, East Asian currencies, regional monetary coordination

\section{Introduction}

Global imbalances have been increasing in 2000s. Related with especially the increasing current account deficits of the United States from 2003 to 2006, a housing investments boom, which was a major factor of the current account deficit in the years, caused the current global financial crisis. Both the global imbalances and the global financial crisis have affected East Asian currencies as well as the US dollar and European currencies.

This paper considers a causality relationship from the global imbalances to the global financial crisis and asymmetric reactions of East Asian currencies to the global financial crisis. In addition, it is pointed out that regional monetary coordination is necessary for stability of intra-regional exchange rates among East Asian currencies. It considers what we should do for the regional monetary coordination in East Asia.

\footnotetext{
Final version accepted 2 August 2009.
}

${ }^{\dagger}$ This paper is a revised version of the 2008 JSIE-Kojima Kyoshi Prize Lecture at the 67th Annual Meeting of the Japan Society of International Economics held at University of Hyogo on October 12, 2008.

* Graduate School of Commerce and Management, Hitotsubashi University. E-mail: ogawa.eiji@srv.cc.hit-u.ac.jp. 


\section{Global Imbalances}

Global imbalances, which means current account imbalances across the world, has been widening in 2000s. The global imbalances include major current imbalances in the United States, East Asia, and oil-exporting countries. Figure 1 focuses on current account imbalances (in terms of GDP) for the United States and East Asia (ASEAN5+3(China, Japan, and Korea)) to show evidence that the movements in the current account deficit of the United States have been symmetrical with those in the current account surpluses of Japan and East Asia.

The current account deficit of the United States has been increasing since late in the 1990s. Causes of the increase in the current account deficit have been changing over time. The increase of the current account deficit late in the 1990s was attributed to increase in investments caused by the IT boom or the IT bubble. The current account deficit kept increasing even after the IT bubble burst. The fiscal deficits which gave stimulus to the U.S. economy increased the current account deficit early in the 2000 s because the increase in fiscal deficits exceeded the decrease in investments in the United States. Easy monetary policy as well as the fiscal deficits started the housing boom and then the housing bubble. At the stage, subprime mortgages and subprime mortgage backed securities have an important role in accelerating the housing boom and bubble, which appeared as the subprime mortgage problem. Combination the increasing housing investments and the fiscal deficits increased the current account deficit from 2003 to 2006 .

The fact that the current account deficit of the United States with East Asia is the most rapidly growing

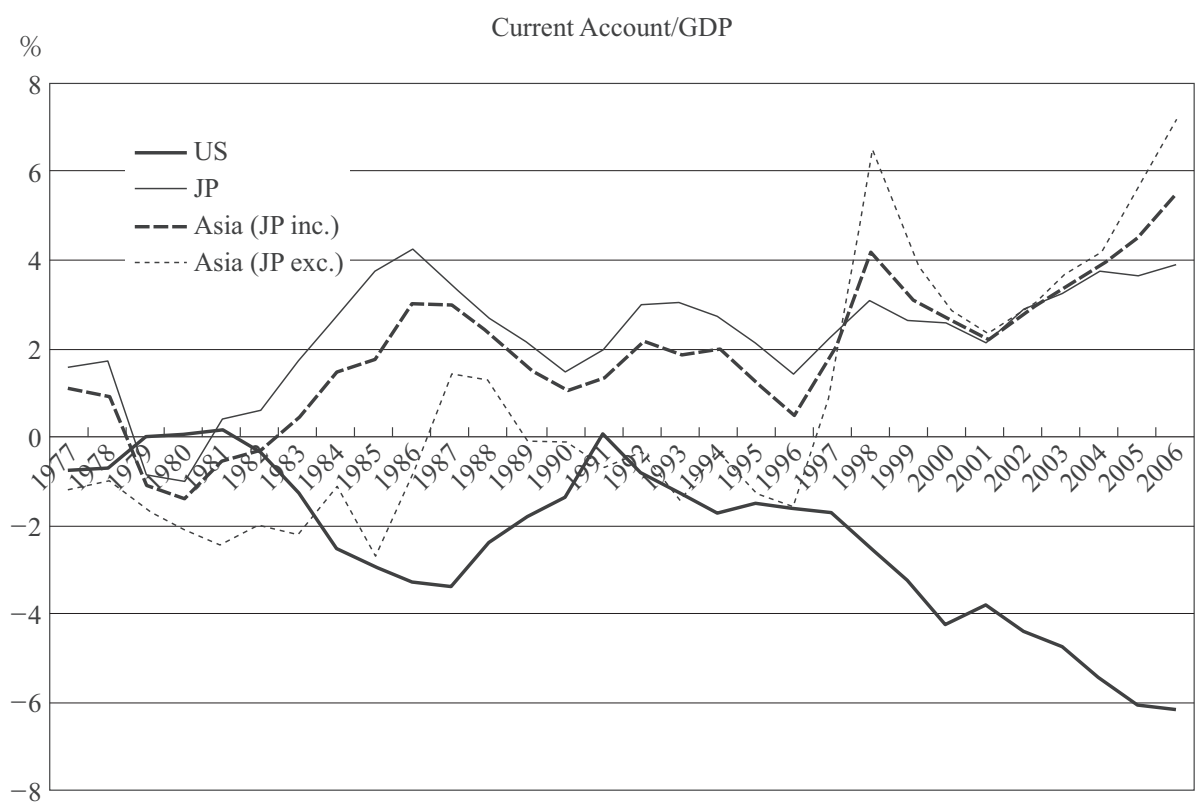

Sourse: Ogawa and Iwatsubo (2009)

Figure 1 Ratios of Current accounts in terms of GDP for the United States, Japan, and East Asia 
component of the current account deficits may indicate, however, that Asian current account surpluses are an alternative cause. Indeed, the "global saving glut" explanation expounded by Bernanke (2005) seeks the cause of current account deficits outside the United States. This argument views the excess saving of Asian countries, due to increased saving and collapsed investment in the aftermath of the financial crisis, as the cause of current account deficits of the United States.

Moreover, current account surpluses in oil-exporting countries increased in a situation of increasing oil price. The current account surpluses had a tendency to have not only direct flows to the United States but also indirect flows via financial institutions in Europe, especially in City, London. The financial institutions have made global financial intermediation between the oil exporting countries and the United States. In other words, the financial institutions in Europe invested in the subprime mortgage backed securities and the related Credit Default Swaps (CDS). In the situation, the subprime mortgage problem has affected not only financial institutions in the United States but also those in Europe.

\section{Sustainability of the US Current Account Deficit}

Many researchers (Mann (2002)) investigated sustainability of the current account deficit in the United States. Among them, Ogawa and Kudo (2007a) explained unsustainable current account deficit in the United States. Methods (unit root and cointegration tests) of Bohn (1995) and Ahmed and Rogers (1995) were used in order to derive the necessary and sufficient conditions for sustainable current account deficit. The sustainability of the current account deficit in the United States was empirically analyzed from a perspective based on domestic investment-saving relationship or international capital flows as well as international trade flows according to Mann (2002). According to Mann (2002), we investigated whether the current account deficit is sustainable in the sense of the external debt solvency, given our empirical analysis during the sample period that covers from the first quarter of 1960 to the fourth quarter of 2002.

The results show that the current account deficit of the United States is unsustainable from viewpoints of international trade flows, domestic saving-investment balance, and international capital flows. On the other hand, when we conduct cointegration tests for a combination of the current account deficit and the financial balance, we found that there is a cointegrating relationship in the combination which includes the current account deficit and the portfolio investment balance. It implies that the current account deficit in the United States has been financed by the portfolio investment from foreign countries to keep a total of the balance of payments in the United States to have a long-run stable convergence to a level. In other words, the unsustainable current account deficit in the United States is stably financed by the capital inflows from foreign countries. 


\section{Exchange Rate Adjustments for Reducing the Global Imbalances}

Ogawa and Kudo (2007b) and Ogawa and Iwatsubo (2008, 2009) used Vector Autoregressive (VAR) or structural VAR models to investigate how impact depreciation of the US dollar would give on the current account imbalances in the United States and each of East Asian countries and how much depreciation of the US dollar is needed to reduce the current account imbalances to a permissible level.

Ogawa and Kudo (2007b) showed that a significant depreciation of the US dollar is necessary in order to reduce the current account deficits. We obtained the robust results that the current account hardly responses to the exchange rate shock from both the views of international trade and the view of domestic saving-investment balance. Accordingly, a sharp depreciation of the US dollar is necessary in order to reduce the US current account deficits to a permissible level.

Ogawa and Iwatsubo (2008) investigated how much realignment of currencies is needed for adjustments to the current account imbalances of Japan compared with those of East Asia as a whole, given the productions networks in East Asia. The analytical results (Table 1) showed that the large realignments of the Japanese yen and other East Asian currencies are needed if the adjustments are completed with only exchange rates. We also found that the degree of the exchange rate adjustments of East Asia as a whole is smaller than that of Japan only.

\begin{tabular}{|c|c|c|c|c|c|}
\hline \multirow{2}{*}{$\begin{array}{c}\text { Country/region } \\
\text { Models }\end{array}$} & \multicolumn{2}{|c|}{ Japan } & \multicolumn{2}{|c|}{$\begin{array}{c}\text { East Asia } \\
\text { excluding Japan }\end{array}$} & \multirow{2}{*}{$\begin{array}{c}\text { East Asia } \\
\text { including Japan } \\
\text { Model EA3 }\end{array}$} \\
\hline & Model J1 & Model J2 & Model EA1 & Model EA2 & \\
\hline \multicolumn{6}{|c|}{ Responses to $1 \%$ appreciation during $50 \mathrm{Q}$} \\
\hline Appreciation & $2.56 \%$ & $10.48 \%$ & $18.52 \%$ & $31.4 \%$ & $6.79 \%$ \\
\hline Reduced CA surplus & $0.23 \%$ point & $0.73 \%$ point & $1.53 \%$ point & $3.61 \%$ point & $0.87 \%$ point \\
\hline $\begin{array}{l}\text { Necessary } \\
\text { appreciation } \\
\text { during 50Q for } \\
2 \% \text { point } \\
\text { reduced CA } \\
\text { surplus }\end{array}$ & $22.3 \%$ & $28.7 \%$ & $24.2 \%$ & $17.4 \%$ & $15.6 \%$ \\
\hline
\end{tabular}

Analytical period: 1991Q1 to 2006Q4

Model J1: four-variable VAR model which includes the real effective exchange rate of the Japanese yen, a ratio of Japanese current account to GDP, Japanese real interest rate, and Japanese GDP growth rate.

Model J2: four-variable VAR model which includes the real effective exchange rate of the Japanese yen, a ratio of Japanese current account to GDP, a ratio of outward FDI to domestic investments, and a ratio of income account to current account.

Models EA1 and EA3: four-variable VAR model which includes the real exchange rate of the weighted average of East Asian currencies in terms of a currency basket of the US dollar and the euro, a ratio of East Asian current account to GDP, East Asian real interest rate, and East Asian GDP growth rate Model EA2: four-variable VAR model which includes the real exchange rate of the weighted average of East Asian currencies to a currency basket of the US dollar and the euro, a ratio of East Asian current account to GDP, a ratio of inward FDI to domestic investments in East Asia, and a ratio of income account to current account in East Asia

Source: Ogawa and Iwatsubo (2008)

Table 1 Exchange rate adjustment to current account imbalance 
Moreover, we investigated why the adjustment becomes more difficult if we rely only on the exchange rates in Japan. We found that Japanese outward FDI has increased independently with the exchange rate and that a ratio of income account to current account has increased due to the FDI. The findings imply that the Japanese economy has an increasing structural part of the Japanese current account which does not respond to the exchange rate movement.

\section{Scenarios of Exchange Rate Adjustments}

Based on the results of simulation analysis (Ogawa and Iwatsubo (2008)), we can consider some scenarios of the US dollar depreciation.

The first scenario is based on the results of simulation analysis (Ogawa and Iwatsubo (2008)). It is assumed that the current fiscal deficit of the United States in 2008 is unchanged in a situation before the global financial crisis in the simulation analysis. It means that consumption and investments of the US private sector as well as the fiscal deficit are unchanged. In the first scenario, about $20 \%$ of appreciation of the Japanese yen and $16 \%$ of appreciation of East Asian currencies are needed to reduce 2\% points of current account surplus of Japan and East Asia.

The second scenario can be considered under an assumption that the subprime mortgage problem reduces housing investments, consumption, and investments in plants and equipments. The reduction would reduces the current account deficits and, in turn, contribute to smaller depreciation of the US dollar. On one hand, the financial crisis in the United States is considered to lose credibility of the US dollar. It would cause a larger depreciation of the US dollar. It is regarded as the third scenario. Lastly, it can be considered as the fourth scenario. For the moment, the US dollar keeps at the current level while the euro and the sterling pound have depreciated against the US dollar very much. Increase in fiscal deficits of the US government from 3\% of GDP in FY2008 to 12\% of GDP in FY2009 might cause a significant depreciation of the US dollar and a harder-landing in the long run.

\section{Asymmetric Responses of East Asian Currencies}

The global financial crisis has affected many currencies. Especially, the euro and the sterling pound have been significantly depreciated since summer in 2008. We can find that some East Asian currencies have made a significant depreciation like the European currencies when we look at East Asian currencies. The response of East Asian currencies reflects in deviation measurements of each East Asian currency based on an Asian Monetary Unit (AMU), that is, a weighted average of East Asian currencies.

When the AMU is calculated, the East Asian currencies include ASEAN10+3 (China, Japan, and Korea) currencies. The weight of each currency in the basket is based on both the countries' respective shares of GDP 
Eiji Ogawa : Global Imbalances and East Asian Currencies

measured at Purchasing Power Parity (PPP), and trade volumes (the sum of exports and imports) in the total of sampled countries for the relevant country. The countries' shares of GDP measured at PPP and their trade volumes are calculated as the average for the most recent three years for which data is available. Also an AMU Deviation Indicator is measured for each of East Asian currencies to deviate from the AMU. ${ }^{1}$ The AMU Deviation Indicators are set to be zero during their benchmark period of two years in 2000 and 2001 when trade imbalances of East Asian countries were the smallest during the recent decade.

Figure 2 shows recent movements of nominal exchange rate of the AMU in terms of a currency basket of the US dollar and the euro as well as in terms of the US dollar and the euro. The currency basket of the US dollar and the euro is composed of the US dollar with $65 \%$ of share and the euro with $35 \%$ of share based on trade shares of East Asian economy with the United States and the euro area in years of 2002-2004 in order to reflect the value of the AMU in terms of the major trading partners' currencies. Figure 2 shows that the AMU has been gradually appreciating against the currency basket of the US dollar and the euro since 2004. It has been at almost the same level in July 2009 compared with the benchmark years 2000 and 2001. On one hand, the AMU has appreciated against the euro while it has been fluctuating against the US dollar since July 2008, which reflected the movements of exchange rate of the euro in terms of the US dollar.

Figure 3 shows movements in deviations of East Asian currencies against the AMU in terms of nominal exchange rates from the benchmark years 2000 and 2001. The Korean won was overvalued more than $20 \%$

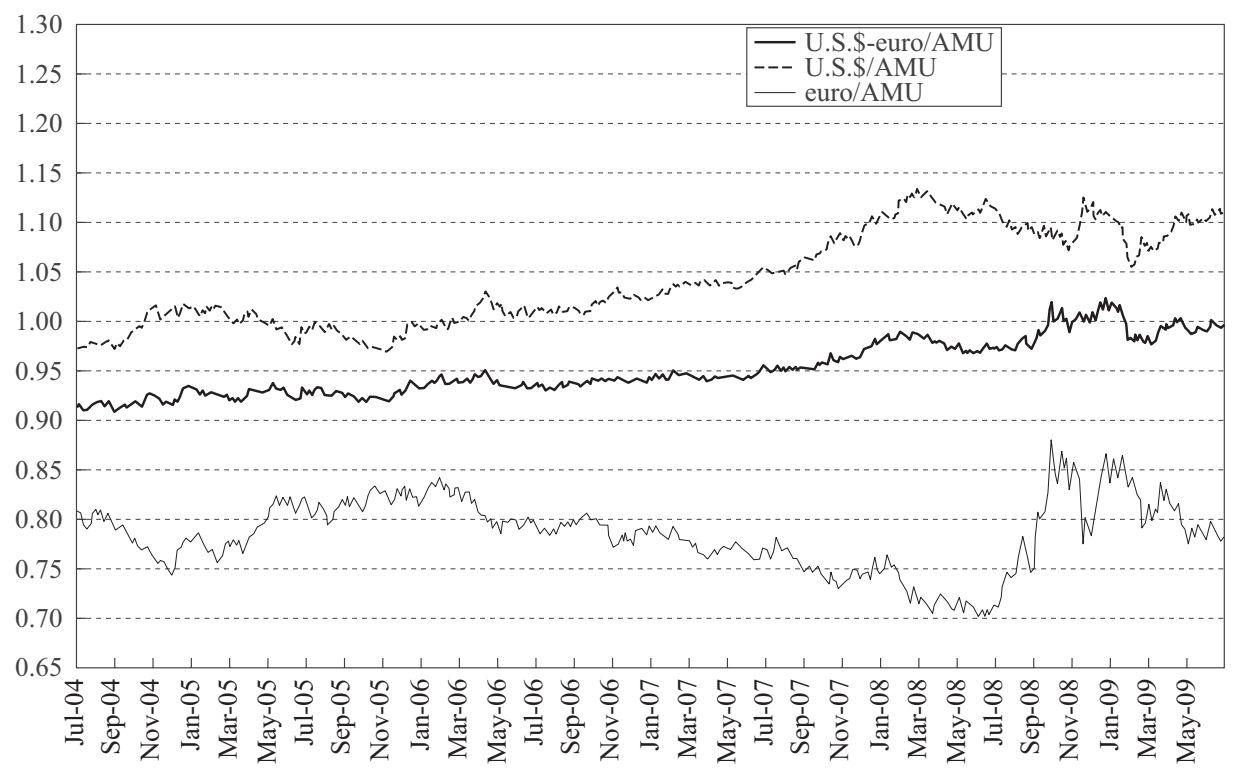

Source: http://www.rieti.go.jp/users/amu/en/index.html

Figure 2 Movements of values of AMU

1) Both the AMU and the AMU Deviation Indicators are available at a website of the Research Institute of Economy, Trade, and Industry (http://www.rieti.go.jp/users/amu/en/index.html). See Ogawa and Shimizu (2005). 


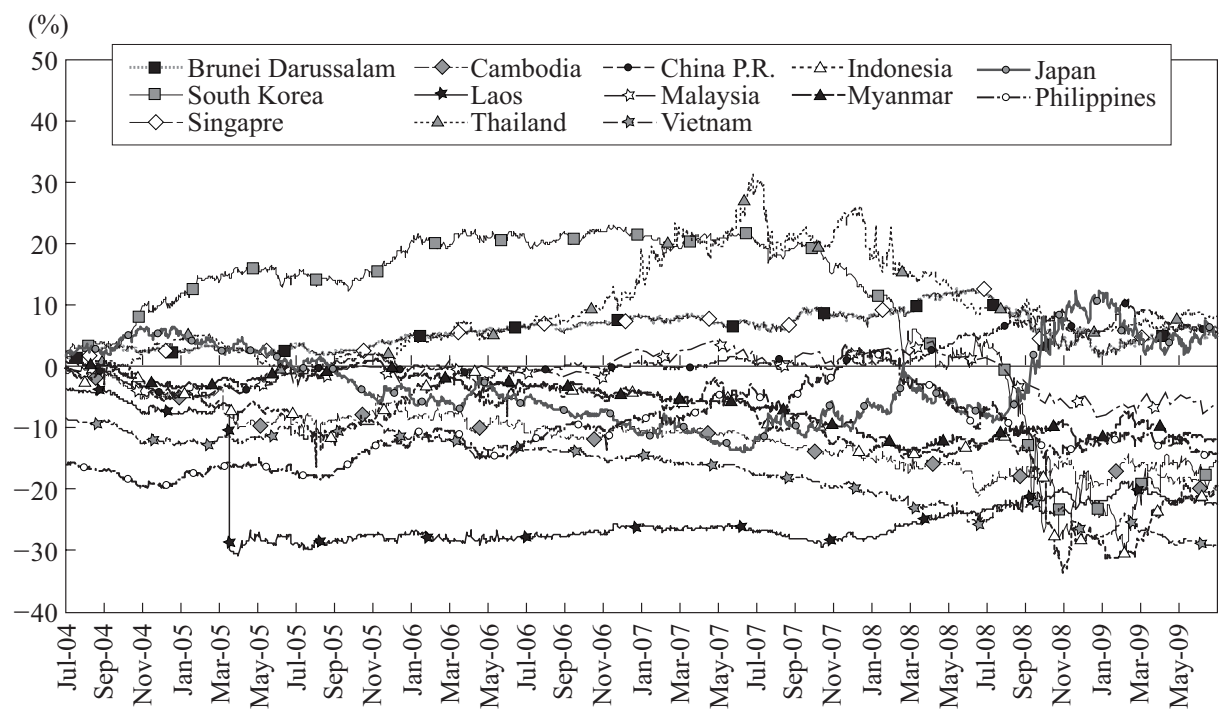

(benchmark year=2000/2001, basket weight=2004-2006, daily)

Source: http://www.rieti.go.jp/users/amu/en/index.html

Figure 3 Nominal AMU Deviation Indicators (daily)

compared with the benchmark years before summer 2007. The Thai baht was appreciating very quickly from the end of 2005 to July 2007. It is overvalued by more than $20 \%$ compared with the benchmark years. On one hand, the Japanese yen was undervalued around 10\% compared with the benchmark years before summer 2007 . However, the Korean won and the Thai baht have been depreciating since summer 2007 while the Japanese yen has been appreciating. Also the Chinese yuan has been appreciating since March 2008.

Figure 4 shows movements in deviations of East Asian currencies against the AMU in terms of real exchange rates from the benchmark years 2000 and 2001. The Real AMU Deviation Indicators of East Asian currencies had been limited within plus $20 \%$ and minus $10 \%$ during a period from 2000 to 2001 . The Korean won had been appreciating against the AMU also in terms of real exchange rates because the appreciation of the nominal exchange rate since the end of 2004. The Thai baht had made a quick appreciation in terms of real exchange rates because of the quick appreciation of the nominal exchange rate since the end of 2006. Both of the currencies have been depreciating since summer of 2007. On the other hand, the Japanese yen has been depreciating because of combination of depreciation of the Japanese yen in terms of nominal exchange rate and the deflation in prices. It has been appreciating quickly since September 2008 while it had been undervalued by nearly $30 \%$ compared with the benchmark years from July 2007 to September 2008.

Thus, the East Asian currencies have the asymmetric responses to the recent global financial crisis. It reflects in intra-regional capital flows such as a yen carry trades in East Asia. On one hand, deviations among the East Asian currencies have been widening in recent years, reflecting the fact that these countries' monetary authorities are adopting a variety of exchange rate systems as shown in Ogawa and Yoshimi $(2008,2009)$. In other words, a coordination failure in adopting exchange rate systems among these monetary authorities increases volatility and 
Eiji Ogawa : Global Imbalances and East Asian Currencies

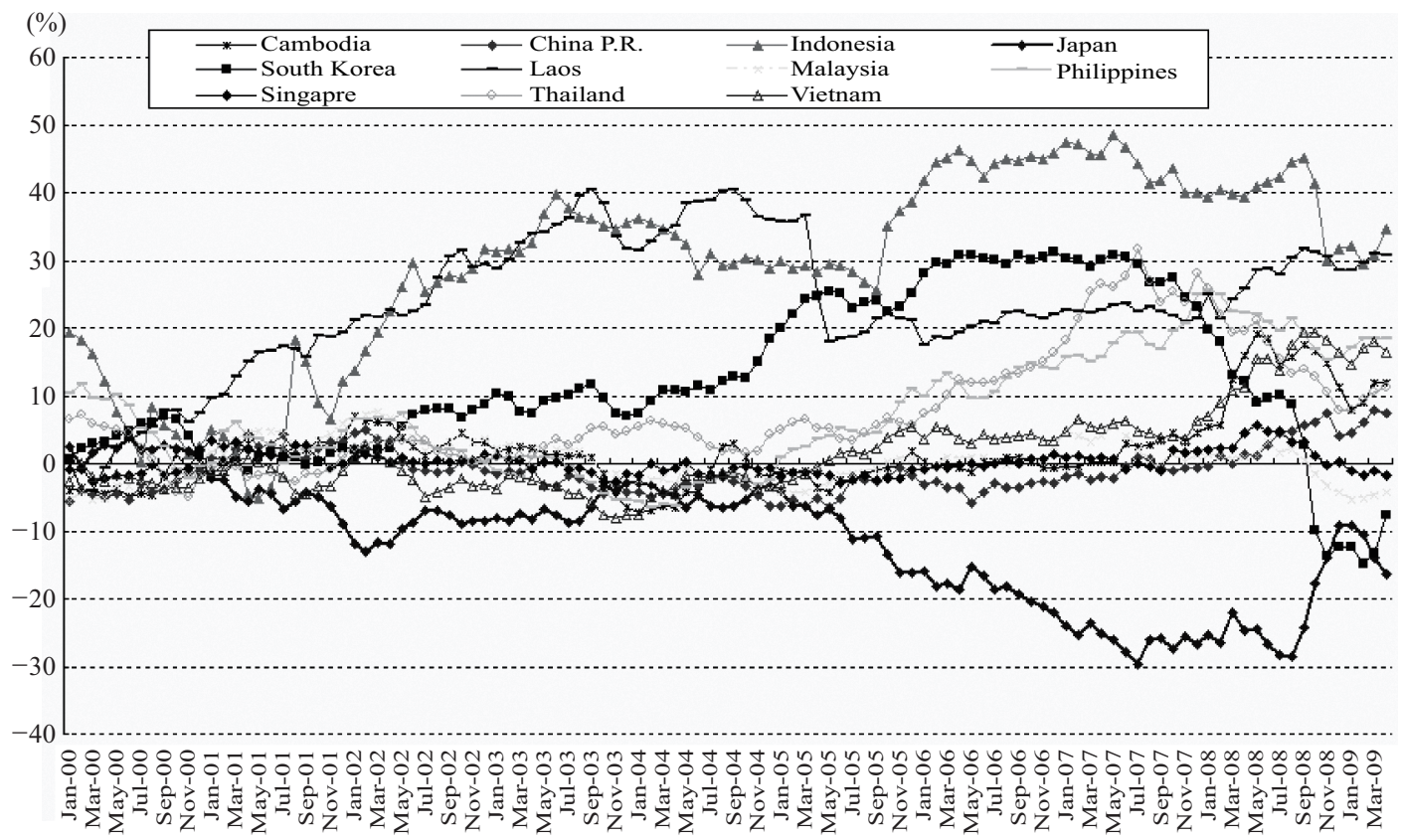

(benchmark year 2000/2001, weight 2001-2006, monthly)

Source: http://www.rieti.go.jp/users/amu/en/index.html

Figure 4 Real AMU Deviation Indicators (monthly)

misalignment of intra-regional exchange rates in East Asia.

\section{Necessity for Regional Monetary Coordination in East Asia}

Ogawa and Ito (2002) pointed out possibilities of coordination failure in choosing exchange rate system and exchange rate policy in a game theoretical framework as long as one country's choosing the dollar peg system has an adverse effect on others' choosing their own exchange rate system through relative price effects. Ogawa (2007) conducted an empirical analysis on whether the dollar pegging currencies gave adverse effects on other East Asian countries' choice of exchange rate system and exchange rate policy. They choose not a desirable exchange rate system but the de facto dollar peg system because the dollar pegging countries keep adopting official or de facto dollar peg systems. In other words, the monetary authorities in East Asian countries face coordination failure in choosing desirable exchange rate system among East Asian countries. Accordingly, it is clear that we should make regional coordination for a desirable exchange rate regime instead of the formal or the de facto dollar peg system.

It is suggested that the dollar pegging countries should adopt more flexible system such as an intermediate exchange rate system that consists both currency basket and exchange rate band. The more flexible system means not a free floating exchange rate system but an intermediate exchange rate system that is located between the free floating exchange rate system and the dollar peg system. It is to suggest that an intermediate exchange rate system 
that consists of both currency basket and exchange rate band. Although especially the Chinese government made announcement of adopting the managed floating exchange rate system with reference to a currency basket on July 21,2005 , the monetary authority has kept targeting stability of the Chinese yuan against only the US dollar (Ogawa and Sakane (2006)). It should implement the managed floating exchange rate system with reference to a currency basket as announced by the Chinese government.

First, under the currency basket system, the monetary authorities should target not the US dollar but a currency basket that is composite of the US dollar, the Japanese yen, and the euro from a viewpoint of international trade and foreign direct investments. East Asian countries have strong economic relationship in terms of international trade, foreign direct investments and international finance with East Asian countries and European countries as well as the United States. Second, under the exchange rate band system, the monetary authorities should set a band in which the exchange rates are free floating without any intervention in the foreign exchange market. The exchange rate band can afford room for domestic monetary policy to the monetary authorities.

The monetary authorities of East Asian countries, especially ASEAN +3 have been strengthening their regional monetary cooperation since the Asian Currency Crisis in 1997 through the Chiang Mai Initiative (CMI). Under the CMI, the monetary authorities of ASEAN+3 established a network of bilateral currency swap arrangements for managing a currency crisis in the member countries. The currency swap arrangements have a condition ("IMF (International Monetary Fund) Link") that a currency crisis country's government can implement the currency swap arrangement only after it requests a financial relief to the IMF. The condition is too restricted for some government such as the Korean government at the current global financial crisis to go to the IMF and, in turn, to implement the currency swap arrangements under the CMI.

Under the CMI, the monetary authorities should conduct a surveillance process for preventing a currency crisis in the future. However, the monetary authorities have not any standing institution for carrying out any surveillance process in East Asia. Instead, they regularly meet as the Economic Review and Policy Dialogue in the ASEAN+3 Finance Deputy Ministers Meeting for surveillance over their macroeconomic performance although they focus on only domestic macroeconomic variables which include GDP, inflation, and soundness of financial sector.

The monetary authorities of East Asian countries should prevent biased changes in the relative prices caused by the US dollar depreciation under the different exchange rate systems in East Asian countries. To do so, they have been coordinated in the choice of their exchange rate systems and exchange rate policies. Kawai, Ogawa, and Ito (2004) suggested the following advices concerning the exchange rate policy in East Asia. First, the monetary authorities of the ASEAN +3 should discuss the exchange rate issue as a part of the surveillance process. They should focus on the exchange rate issue as well as on the domestic macroeconomic policies and on the soundness of financial sector: the exchange rates of home currencies against neighboring countries' are indeed linked by its terms of trade and its competitive prices. Each country in the East Asia region has strong economic relationships with the other intra-regional countries as well as the United States and the European countries. 
Eiji Ogawa : Global Imbalances and East Asian Currencies

Intra-regional exchange rates among East Asian currencies should affect economic activities in each country of East Asia through intra-regional trade, investments, and finance. The monetary authorities should not only hold under account movements of the exchange rates but also their deviations from the regional averages and, in turn, their exchange rate policies per se.

The surveillance process, in itself, might not be sufficiently solid to preserve the regional policy coordination in the long run because the monetary authorities of each country are not committed to the policy coordination. They may make a limited contribution to the policy coordination. It is necessary to have a mechanism that will be able to preserve the regional coordination in the long run by compelling the monetary authorities to be committed to the regional policy coordination.

Regarding the regional policy coordination, it is necessary that all the monetary authorities in the region agree on an arrangement to create a regional common unit of account that consists of a basket of regional currencies. They might make a commitment to follow the regional common unit of account in carrying out their exchange rate policy. It is desirable to create a regional common unit of account to which monetary authorities of East Asian countries should target in conducting their exchange rate policies in order that they should make regional policy coordination for their exchange rate policies with each other. To do so, a Regional Monetary Unit should be introduced as a regional common unit of account into East Asia. For this purpose, a common currency basket that includes regional currencies of the ASEAN +3 countries is created. ${ }^{2)}$ A research group under the ASEAN +3 Financial Ministers Meeting studied possibility of introducing a Regional Monetary Unit for coordinated exchange rate policy to propose the Regional Monetary Unit to the ASEAN+3 Financial Ministers Meeting.

\section{Conclusion}

This paper focused on the global financial crisis that started in the United States in 2007. In terms of global currencies, the global financial crisis has brought about shortages of the US dollar liquidity in especially European economy. The similar phenomenon has seemed to occur in Korean economy. In these economies, the home currencies have significantly depreciated especially since summer 2008. On one hand, the US dollar has possibility of depreciating in the near future situation where the fiscal deficit of the US government will increase from 3.4\% of GDP in FY2008 to 12.3\% of GDP in FY2009 and then about 6\% of GDP within next four years.

Reflecting the global financial crisis, the East Asian currencies have made asymmetric responses against the US dollar. The Korean won and the Thai baht have depreciated while the Japanese yen has appreciated. In fact, deviations among the East Asian currencies have been widening in recent years, reflecting the fact that these countries' monetary authorities are adopting a variety of exchange rate systems. In other words, a coordination

2) Ogawa and Kawasaki (2008) conducted an empirical analysis on possibility of introducing a common currency basket arrangement to East Asian countries. 
failure in adopting exchange rate systems among the monetary authorities increases volatility and misalignment of intra-regional exchange rates in East Asia.

The monetary authorities should make regional coordination to reduce volatility and misalignment of intraregional exchange rates. They can use the policy dialogue at the Economic Review and Policy Dialogue in the ASEAN+3 Finance Deputy Ministers Meeting under the CMI to make surveillance over the intra-regional exchange rates. At the same time, the currency swap arrangements under the CMI should be further strengthened in terms of quantity and quality. Among them, the IMF Link should be reduced by establishing a standing institution for carrying out any surveillance process in East Asia so as not to rely on the IMF in terms of their surveillance.

\section{References}

[ 1 ] Ahmed, S. and J. H. Rogers (1995) "Government Budget Deficits and Trade Deficits: Are Present Value Constraints Sustained in Long-term Data?" Journal of Monetary Economics, 36, 351-374.

[2 $]$ Bernanke, B. S. (2005) "The Global Saving Glut and the U.S. Current Account Deficit," Remarks at the Sandridge Lecture, Virginia Association of Economics, Richmond, Virginia, Mach 10, 2005.

[ 3 ] Bohn, H., (1995) "The Sustainability of Budget Deficits in a Stochastic Economy," Journal of Money, Credit and Banking, 27, 257-271.

[ 4 ] Kawai, M., E. Ogawa, and T. Ito (2004) "Developing New Regional Financial Architecture: A Proposal," mimeo.

[ 5 ] Mann, C. L. (2002) "Perspectives on the U.S. Current Account Deficit and Sustainability," Journal of Economic Perspectives, 16, 131-152.

[ 6 ] Ogawa, E. (2007) "Economic interdependence and international coordination in East Asia," in Takatoshi Ito, ed., $A$ Basket Currency for Asia, Routledge, Pub., 99-123.

[ 7 ] Ogawa, E. and T. Ito (2002) "On the Desirability of a Regional Basket Currency Arrangement," Journal of the Japanese and International Economies, vol. 16, No. 3, 317-334.

[ 8 ] Ogawa, E. and K. Iwatsubo (2008) "External Adjustments under Increasing Integration: Japanese Perspective," a paper prepared for PEO/Structure Specialist Meeting on "External Adjustments under Increasing Integration" that is held in Osaka on September 6-7, 2008.

[ 9 ] Ogawa, E. and K. Iwatsubo (2009) "External Adjustments and Coordinated Exchange Rate Policy in Asia," Journal of Asian Economics, 20, 225-239.

[10] Ogawa, E. and K. Kawasaki (2008) "Adopting a Common Currency Basket Arrangement into the ASEAN Plus Three,": in Takatoshi Ito and Andrew K. Rose ed., International Financial Issues in the Pacific Rim: Global Imbalances, Financial Liberalization, \& Exchange Rate Policy, University of Chicago Press, 219-234.

[11] Ogawa, E. and T. Kudo (2007a) "Possible depreciation of the US dollar for unsustainable current account deficit in the United States," CESifo Forum, Vol.8, No.4, 24-30.

[12] Ogawa, E. and T. Kudo (2007b) "Asymmetric responses of East Asian currencies to the US dollar depreciation for reducing the US current account deficits," Journal of Asian Economics, 18, 175-194.

[13] Ogawa, E. and M. Sakane (2006) "Chinese Yuan after Chinese Exchange Rate System Reform," China \& World Economy, Vol.14, No.6, 39-57.

[14] Ogawa, E. and J. Shimizu (2006) "AMU Deviation Indicators for Coordinated Exchange Rate Policies in East Asia 
Eiji Ogawa : Global Imbalances and East Asian Currencies and their Relationships with Effective Exchange Rates," The World Economy, vol.29, Issue 12, 1691-1708.

[15] Ogawa, E. and T. Yoshimi (2008) "Widening Deviation among East Asian Currencies", RIETI Discussion Paper Series, 08-E-010.

[16] Ogawa, E. and T. Yoshimi (2008) "Analysis on $\beta$ and $\sigma$ Convergences of East Asian Currencies," RIETI Discussion Paper Series, 09-E-018. 